\title{
THE DEMOCRACY OF UNIVERSAL MILITARY SERVICE
}

\author{
By Franklin H. Giddings, LL.D.,
}

Professor of Sociology and History of Civilization, Columbia University.

This topic is resolvable into propositions of the indispensable science of guess work. There is no way of knowing what the effect of a large military and naval establishment on our domestic institutions and policy will be. The factors of causation are many, and the contingencies are uncertain. Nevertheless, we must guess as well as we can. Marvellous as the achievements of experimental science have been, and great as the accumulations of verified knowledge are, mankind yet goes on its daily way, in matters social and political, by guessing. It becomes important, therefore, to guess well. For practical purposes the difference between good guessing and bad guessing is incalculable. The social and political sciences are attempts to establish principles and methods of good guessing, in these domains. Encouraging progress has been made since this Academy was founded twenty years ago. It is this progress that we celebrate today.

The fundamental principles of good guessing are no other than those of scientific method in general and perhaps this fact offers as good a reason as any that could be found in justification of our temerity in speaking of social and political sciences. A careful discrimination of facts, qualities, and kinds of things, one from another, is the first requirement. Painstaking measurement, or estimate, of quantities is the second requirement. In attempting to guess what the effect of a large military and naval establishment upon our domestic institutions and policy will be, we shall plunge wildly unless we keep these requisites of method continually in mind.

What, then, are we to understand by the phrase, "A Large Military and Naval Establishment"? We are a nation of more than one hundred million souls. An army of one million men would have been impossibly large for the United States one hundred years ago, when our total population did not exceed five million persons, men, women, and children all told. It would have in173 
cluded every male of military age, without allowance for invalids, cripples, and other incompetents. Would an army of one million men now be large? It would be less than one per cent of the population; it would be approximately five per cent of the male population of military age. To the cold-blooded statistician the figure is not of disturbing magnitude. To the sensitive soul of the pacifist, it is monstrous. Let us try to arrive at a view acceptable to a reasoning and commonsensible mind.

I admit that, at the moment, there is a painful failure to agree upon what or who the reasoning and commonsensible minds are. The pacifists have of late been exploiting the vocabulary of neurasthenic description. Their favorite words are, "hysteria," "hysterical," "fright," "epidemic of fear." I shall not argue with them about the mental state of those advocates of preparedness to whom these terms are so freely and unremittingly applied. I will only remind you, whom I now address, and who, I assume, are ladies and gentlemen of scientific temper, that one of the well-recognized symptoms of real hysteria - the genuine thing -is the indestructible conviction of its victims that the normal people round about them are hysterical.

Returning to tangible things: for a period nearly as long as the life of this Academy thus far, the world's example and measure of militarism has been the military strength, organization, equipment, and military morale of Germany. The normal make-up of this surpassing military force consists of a standing army, in time of peace, of 870,000 men, reserves of $4,530,000$, men all thoroughly instructed, drilled, and equipped, and an available but unorganized force of $8,162,400$. The population supporting this establishment is less than 70,000,000 persons. Leaving out of account the unorganized forces, and counting only the instructed and organized forces, the six greater nations of Europe, namely, Germany, AustriaHungary, France, Russia, Italy, and Great Britain normally have an immediately available military force of more than 25,000,000 men. It will generally be admitted, I suppose, that military preparedness of this magnitude may, without exaggeration, be described as militarism.

The area of Europe, which its $25,000,000$ to $30,000,000$ soldiers are expected to defend or to devastate, as occasion arises, is $3,754,282$ square miles. The area of the United States, plus the area of 
Alaska and the area of our island possessions, is 3,743,306 square miles, or only 10,979 square miles less than the total area of Europe.

If we had a peace-footing army of one million men, and trained reserves of five million men, we should have for the protection of our continental area, Alaska, and island possessions, less than one fifth of the military establishment maintained upon the equal area of Europe; Japan and all other nations being left out of the reckoning. It is permissible to any free born American to call such a measure of preparedness "militarism" if he wants to. There are intellects, here and there, that function that way.

So I offer my first contribution to our guessing match upon the probable effect of a large military establishment in the United States. My guess is that a peace-footing army of one million men, and a trained reserve force of five million more men would have, so far as any reaction of mere magnitude is concerned, absolutely no effect whatever upon our American domestic life. It would be neither more nor less appreciable than a police force of 15,000 men in this city of Philadelphia, with its population of more than one million and a half inhabitants.

The magnitude, however, of a military establishment is by no means the only or the most important factor to be regarded when forecasting its probable reactions. Far more important than any dimensions that we are likely to have to consider, is the character or type of the army that we might create in the United States. Like England we have been, and are now, committed to a hired or professional army which, next after monarchy and hereditary rank, is the most undemocratic thing that man has so far invented. A hired army does not have to be large to establish undemocratic standards and to cause mischievous irritation. When the European War is over, the class struggle will break forth afresh, with fourfold energy. I think that we may confidently anticipate that the forces of organized labor and of socialism will actively oppose professional armies. Rightly or wrongly they will insist that a professional army may, at any time, be used by a dominant capitalism to quell strikes and to put down an industrial revolution.

International socialism, to its honor, is opposed to all preventable war, but it does not feel about universal military service as it feels about a hired and professional army. Universal military training puts all citizens on the same footing. The proletarian, 
like the man who hires him, is taught the manual of arms, and, in the event of war, the man who hires him is equally liable with other men to take his chance in the trenches.

Many of you here present doubtless remember, as I do, the bitterness engendered by that form of conscription to which the federal government resorted in our Civil War. My father was the minister of a Congregational church in a country village, and I vividly recall my impressions of scenes in our home when women in humble circumstances came for a word of comfort, holding in trembling hands the tear-blotted scrap of paper that told of the death of husband or son, and, child as I was, I felt their smarting sense of injustice that their loved ones had to go to the battle field while the relatively well-to-do manufacturer and the merchant could buy substitutes. I do not need to argue, for you all know, that the worst of England's troubles in the present war have been directly attributable to her initial reliance upon an inadequate professional army, helped out by volunteers; while the superb democratic solidarity of France is attributable to the equality and justice of a universal military requirement, which puts all men of high or low degree on the same footing in the face of suffering and fate.

So I make my second guess, which is that if we create a hired army of more than half a million of men, and do not back it up by some form of universal military requirement and training, we shall engender irritation and distrust; we shall unnecessarily intensify the class struggle; and we shall disintegrate such democratic solidarity as we yet enjoy. Whereas, if we follow the examples of Switzerland and of France; recognize the responsibility of every able bodied citizen for the defence of his country; give every man a good, but not too exacting military training, we shall inspire all citizens with the conviction that our institutions are founded in justice and duty, and shall thereby invigorate our democracy.

These possible reactions of a larger military establishment are, I conceive, the most important ones to take account of. There are others not to be ignored. I will content myself with a brief consideration of two.

It is generally acknowledged by unprejudiced persons that military training may have an educational value. I count myself fortunate that in my college days I enjoyed such training for a 
time, under the instruction of Captain, afterwards General, Thomas Ward of the Regular Army. I learned many valuable things that, as it turned out, I should have had no other opportunity in my life to learn, and that on the whole have contributed to my physical health, my sense of social duty, and my comprehension of the importance of efficiency in team work. Incidentally I learned, I think, the moral no less than the marching distinction between guiding right and guiding left, and I have since been trying to "guide right."

It is urged by men whose intelligence and distinction carry great weight that all of the educational advantages of military discipline may and should be obtained through other means. Cannot setting up exercises, coöperative activity, accuracy, regular habits, and all the rest be taught apart from their associations with war? Undoubtedly they might be, and they should be. Nevertheless, they are not, in our schools or in our colleges. After lifelong association with educational interests, I regret to have to say that I see very little reason to expect that these disciplines will be effectively developed in America unless the demand for them comes from the same source that has demanded and obtained them in continental Europe and in Australia. It is a thing one would rather not say, but it is true: we are a loose-minded and a loose-mannered people. Money making, and fads invented by lunatics are the only things that we take seriously. I share the conviction, which has been growing in many minds, that this deplorable state of mind, and of behavior is in no small measure the consequence of our fatuous custom of letting our young people "go on the loose," instead of holding them to tasks, duties, discipline, and achievement.

As a fact of experience it seems not to be true that the average man will do the things that he should do merely because they are expedient and right. He does them under economic or social pressure. Economic pressure in the United States, by comparison with economic pressure in the old world, has been relatively light; and our social pressure is formless and relatively ineffective because, in cutting loose from the aristocratic traditions and conventions of an older world community we have, at the same time, cut loose from a priceless heritage of human wisdom, in the vain thought that the laws of the universe are suspended in the Western Hemisphere.

Among the precepts of wisdom that we have been trying des- 
perately to ignore is the truth that human beings do not do things for their health, bodily or spiritual, until their health is gone. They do things in the day's work because they have to; they do things for fun because they like to. The well set-up "cop," the fireman, the middy, and the soldier, do not take their exercises and their drills because they have reasoned that such exertions are good for them; they take them under social pressure, because they have to, on penalty of losing their jobs.

Here we have the crux of the whole question of the educational value of military training. Education as education, school boys and college boys do not take seriously in this country, and they will not take it seriously until they feel a social pressure more effectively organized than any we now have. Young men do take military training seriously, they are set up and disciplined by it because they feel that it is linked to tremendous realities, because it is a recognition of the solemn fact that nations have been obliged to repel invasion and to put down insurrection, and that the necessity may arise again. It is associated with convictions of obligation, with love of country, with loyalty and obedience.

Yes, with obedience. I am well aware that one half at least of that opposition to preparedness which parades as pacifism is neither more nor less than an anarchistic revolt against the teaching of obedience. I should be in sympathy with it if obedience were now, as in other days it was, submission to irresponsible power or authority. But obedience today, in America at least, as in Switzerland and in France, is another thing. It is a loyal and rational acquiescence in the general will; it is the act of being republican; it is the act of being democratic as distinguished from the verbal democracy of the humbug and the blatherskite. And this democracy of act, of loyal obedience to the general will, of willing sacrifice for the general good, is the republicanism that we need; it is the democracy that we must have if we are to be a nation respecting ourselves, and worthy of the world's respect.

Upon the second of the possible minor reactions of a larger military establishment than we have hitherto had in the United States, I shall be still more brief. Is there danger that by recognizing the importance of general military training, and by adopting it, we shall become interested in military operations for their own sake, and insensitive to the dreadfulness of war? Granting that 
the maintenance of an adequate army of defence, and a powerful navy would not in itself be militarism, should we, nevertheless, by creating such establishments be entering upon a perilous course, leading to militarism in the end? My answer to this question is like the answers that I have given to the questions already considered. I call your attention to certain facts and discriminations. Where, in all human history, do you find that republican and democratic populations have become militaristic? Where, in all human history, do you find monarchies that have not become, or tended to become militaristic? Militarism is not a simple phenomenon; it is a highly complex product of many factors intricately combined. Monarchism harks back to ancient days, to reactionary instincts; it is intrenched in privilege; it resists change. But mankind progresses. Progress endangers monarchy; it threatens it with overthrow. Monarchism as such cares nothing for the populace, except as a base of supply and a fighting force. Monarchy is excited by progress; it casts about for policies to turn progress to its own account; militarism is the sum of the policies that it adopts. Militarism is, in fine, a policy of monarchy excited by progress. Democracy has nothing to gain by aggressive war-but everything to lose. Both instinctively and rationally democracies realize that such is the truth. Their danger lies not at all in a possible drift toward militarism; it lies rather in a failure to grasp the complexities of international interests and relations as they stand in the world today; in a failure to realize that good behaviour by the well-intentioned is no protection against aggression by the ruthless. The danger of republics and democracies lies in the immense difficulty of arousing democratic masses to an appreciation of the importance of forecast, of preparation, of timely organization, of the development of efficiency to meet contingencies not only possible but, in the imperfect and by no means righteous world of today, in the highest degree probable.

What I have said about the probable reactions of a larger military establishment on land applies, I think, in the main, to the question of the probable effect upon our domestic life and institutions of a large naval establishment. We may safely assume that the United States does not need the largest navy in the world, or even a navy as large as that of Great Britain. But we have long lines of coasts to protect, and the outlying possessions of Alaska 
and our Pacific Islands. By creating a navy second to that of Great Britain, and larger than any other, we should merely measure our naval strength according to the amount of work that it may be called upon to perform. And I offer as my final guess in this discussion that neither individual nor nation can undermine character or endanger free institutions by foresight of events, evidence, provision of appliances, and discipline of strength according to the measure of responsibility and of obligation. It was not an alarmist who said: "He that provideth not for his own, is worse than an infidel." 